\title{
СИСТЕМНИЙ СИНЕРГЕТИЧНИЙ ПІДХІД ДО ФОРМУВАННЯ НАУКОВО-ДОСЛІДНИЦЬКОЇ КОМПЕТЕНТНОСТІ МАЙБУТНІХ ФАХІВЦІВ-ЕКОЛОГІВ
}

\section{І. О. Солошич}

Кременчуцький національний університет імені Михайла Остроградського

вул. Першотравнева, 20, 39600, м. Кременчук, Україна. E-mail: soloishych@gmail.com

Розглянуто основні аспекти використання системного синергетичного підходу до формування науководослідницької компетентності майбутніх фахівців-екологів. У ході дослідження розкрито сутність понять «система», «системний синергетичний підхід», елементи структури педагогічної системи. Сучасну сферу екологічної освіти розглянуто як складну, відкриту, нелінійну, нерівноважну систему, здатну до самоорганізації. Наведено приклад застосування системного синергетичного підходу при формуванні науково-дослідницької компетентності майбутніх фахівців-екологів за допомогою розробленої інформаційно-пошукової системи очисного обладнання, що дозволяє сформувати інтегративні знання з екології та 3 інших галузей знань (фізики, хімії, біології, та технологій). Доводиться, що системність професійної екологічної освіти зумовлює необхідність застосування системного синергетичного підходу під час формування науково-дослідницької компетентності у майбутніх фахівців-екологів.

Ключові слова: системний синергетичний підхід, інформаційно-пошукова система очисного обладнання, науково-дослідницька компетентність, майбутні фахівці-екологи.

\section{СИСТЕМНЫЙ СИНЕРГЕТИЧЕСКИЙ ПОДХОД К ФОРМИРОВАНИЮ НАУЧНО-ИССЛЕДОВАТЕЛЬСКОЙ КОМПЕТЕНТНОСТИ БУДУЩИХ СПЕЦИАЛИСТОВ-ЭКОЛОГОВ}

\section{И. А. Солошич}

Кременчугский национальный университет имени Михаила Остроградского

ул. Первомайская, 20, 39600, г. Кременчуг, Украина. E-mail: soloishych@ gmail.com

Рассмотрены основные аспекты использования системного синергетического подхода к формированию научно-исследовательской компетентности будущих специалистов-экологов. В ходе исследования раскрыта сущность понятий «система», «системный синергетический подход», элементы структуры педагогической системы. Современную сферу экологического образования рассмотрено как сложную, открытую, нелинейную, неравновесную систему, способную к самоорганизации. Приведен пример применения системного синергетического подхода при формировании научно-исследовательской компетентности будущих специалистов-экологов с помощью разработанной информационно-поисковой системы очистного оборудования, что позволяет сформировать интегративные знания по экологии и других отраслей знаний (физики, химии, биологии, и технологий). Доказывается, что системность профессионального экологического образования вызывает необходимость применения системного синергетического подхода при формировании научно-исследовательской компетентности у будущих специалистов-экологов.

Ключевые слова: системный синергетический подход, информационно-поисковая система очистного оборудования, научно-исследовательская компетентность, будущие специалисты-экологи.

АКТУАЛЬНІСТЬ РОБОТИ. Характерною особливістю минулого століття став стрімкий економічний і технологічний розвиток. 3 одного боку, техніка $є$ джерелом небаченої продуктивності щодо умов людського існування, $з$ іншого - іiі розвиток спричиняе підрив і навіть унеможливлення існування людини [1].

Ігнорування законів природи призводить до незворотних наслідків, екологічної кризи, одним із наймогутніших важелів виходу з якої $є$ екологічна освіта.

В умовах постійної зміни характеристик і динаміки розвитку суспільства, робота фахівців-екологів все більшою мірою модифікується і набуває науково-дослідницької спрямованості, що передбачає участь у проектній діяльності, проведенні наукових досліджень, направлених на вирішення екологічних проблем.

Тому в сучасному суспільстві почав формуватися попит на висококваліфікованих фахівцівекологів, які володіють дослідницькими вміннями і навичками, здатних до креативного мислення, творчої праці, професійного саморозвитку, освоєння та впровадження у виробництво наукоємних природоохоронних технологій.

Мета статті полягає у висвітленні системного синергетичного підходу до формування науководослідницької компетентності (НДК) майбутніх фахівців-екологів (МФЕ).

Дослідження було проведено із застосуванням системного синергетичного підходу, за допомогою загальнонаукових методів аналізу, синтезу та порівняння.

МАТЕРІАЛ І РЕЗУЛЬТАТИ ДОСЛІДЖЕНЬ. В сучасній науково-педагогічній літературі багато уваги приділено різним аспектам застосування системного синергетичного підходу в освітньому процесі, оскільки він є провідним у сучасному науковому пізнанні.

Науковим підгрунтям для розкриття заявленої теми стали праці, що розкивають сутність системного підходу таких учених, як В. Афанасьєва, Г. Александрова, Ю. Бабанського, В. Безпалька, О. Глузмана, Л. Зоріної, Т. Ільїної, М. Кагана, Г. Серикова та iн.

Системний підхід в екологічній освіти розгляда- 
ється в працях Г. Білецької, В. Боголюбова, Ю. Гришаєвої, Г. Пустовіт, Г. Сорокіної та ін. Наукові дослідження В. Аршинова, О. Вознюка, Л. Свстигнєєвої, Р. Євстигнєєва, О. Князєвої, С. Курдюмова, В. Кременя, В. Лутая, М. Таланчука, С. Цюри, Ю. Шароніна та ін. висвітлюють використання синергетичного підходу в педагогічній теорії і практиці.

Науково-теоретичним засадам системного підходу до вирішення проблеми формування науководослідницької компетентності присвячено роботи П. Горкуненко, М. Князян, Є. Кулик, В. Прошкіна, Л. Султанова, М. Фалько та ін.

Для використання системного синергетичного підходу при формуванні НДК у МФЕ розглянемо визначення основних понять системного синергетичного дослідження. Теоретичний аналіз проблеми засвідчив, що існують різноманітні трактування поняття «система». Наведемо деякі з них, що становлять інтерес у контексті нашого дослідження.

Система (грец. systema - ціле, що складається 3 частин) є сукупність взаємопов'язаних компонентів, які утворюють цілісність [2].

На думку В. Афанасьєва система є «сукупністю об’єктів, взаємодія яких обумовлює наявність нових інтегративних якостей, не властивих частинам, що іiі утворюють» [3]. Систему як скінченну множину елементів, об'єднаних динамічними й статичними відношеннями, яка забезпечує наявність цілеспрямованих властивостей, що дозволяють розв'язувати системопороджувальне протиріччя в зовнішніх умовах розуміє В. Сагатовський [4].

В. Афанасьев вважає, що характерною особливістю системи $є$ те, що вона має нові якісні характеристики, не властиві для іï складових, на них більше впливає їі структура, ніж склад [3].

В. Ільїн виділяє елементом системи мінімальну структуро-утворюючу одиницю, що характеризується функціональною і структурною специфічністю, та інтегративністю [5].

Таким чином вважаємо, що система є цілісність взаємодіючих, взаємопов'язаних між собою компонентів, спроектованих для досягнення певної мети, яка породжує системну якість.

Погоджуємся 3 думкою О. Глузмана, що педагогічний процес $є$ цілісною науково-освітньою системою, яка має зміст, структуру та функції з взаємозв'язком, єдністю функціонування, внутрішню впорядкованістю компонентів і взаємовідношенням між ними [6].

Г. Александров подає поняття педагогічної системи у вигляді

$$
\sum:\{\{M\} ;\{x\} ; F ; G\},
$$

де $\{\mathrm{M}\}$ - множина іï елементів, $\{\mathrm{x}\}-$ множина зв'язків і відношень між ними, F - функція (нова властивість системи), що характеризує ії інтегративність і цілісність, $\mathrm{G}$ - системоутворюючий чинник [7].

Грунтуючись на розробках авторів [2-7], беручи за основу дослідження В. Прошкіна [8], вважаємо, що особливістю педагогічних систем $є$ те, що вони: функціонують в умовах зміни різних чинників зов- нішнього оточення та внутрішніх станів системи, що викликані цими чинниками; мають відносну незалежність від зовнішнього середовища й оточення; постійно розвиваються, вдосконалюються, самоорганізуються.

На думку Т. Ільїною ефективність педагогічної системи пропорційна ступеню іiі цілісності й силі зв'язків між елементами і залежить від іії сумісності 3 навколишнім середовищем і ступеня відповідності організаційної сторони тим цілям, для досягнення яких її було створено [9].

Ми підтримуємо думку вчених $[10,11]$ щодо логіки дослідницької роботи зі створення педагогічної системи й вважаємо за необхідне розробити вимоги до педагогічної системи формування НДК у МФЕ: цілісність, що полягає в гармонійній згоді й залежності між об'єктними областями; стабільність, яка передбачає здатність системи функціонувати, не змінюючи власної структури, і знаходитися в рівновазі; відкритість, яка є властивістю системи, що показує, чи можна за виходом повністю відновити інформацію про стани системи; оглядовість, яка полягає в необхідності включення в модель допустимо мінімальної кількості параметрів.

Відтак, зважаючи на ідеї фахівців з питань професійної підготовки (С. Батишева, Б. Гершунського, А. Маркової, В. Сластьоніна, В. Ягупова та ін.), будемо розглядати професійну підготовку МФЕ як систему, що складається 3 цільової, змістової, технологічної та діагностичної взаємопов'язаних компонентів, оскільки цілі визначають зміст, який впливає на вибір педагогічних технологій, що, в свою чергу, зумовлює організацію системи контролю.

Педагогічна система формування НДК у МФЕ $\epsilon$ сукупністю взаємопов'язаних суб'єктів освітнього процесу та умов, в яких цей процес здійснюється, тому системність фахової підготовки зумовлює необхідність застосування системного підходу під час їх навчання.

Спираючись на роботи В. Беспалька, Г. Білецької, В. Прошкіна, визначимо структуру педагогічної системи формування НДК у МФЕ, яка складається 3 компонентів: цільового (мети, завдання, результату); суб'єкт-об'єктного (взаємодія викладачів та студентів); змістового (форми формування НДК); технологічного (педагогічна технологія формування НДК); мотиваційно-стимулюючого (механізми стимулювання викладачів і студентів до наукової діяльності); діагностичного.

Аналіз наукової літератури [1-12] дає можливість стверджувати, що поняття «система» і «системний підхід» пов'язані між собою, тому що в їх основі лежить розгляд об'єкта як системи.

Засновниками системного підходу є Чарльз Дарвін, Карл Маркс, Г. Гегель та ін., які використовували ідеї системності, досліджуючи біологічний світ і людське суспільство [13].

Системний підхід передбачає спрощення реальної ситуації, виділення головного (у рамках конкретного завдання) й абстрагування від несуттєвого, обліку й аналізу всіх компонентів системи та взаємозв'язків між ними [11]. Нам імпонує думка Г. Се- 
рикова [14] та Г. Білецької [12], які вважають, що використання системного підходу в професійній освіті дає можливість поєднувати як традиційні принципи освітнього процесу, так і нові підходи, що сприяє забезпеченню інтеграції загальнонаукової і спеціалізованої професійної підготовки.

Слід зазначити, що традиційна система освіти $є$ закритою системою, тому втрачає свою здатність до саморозвитку та не може ефективно виконувати роль засобу освоєння сучасного світу. «Зусилля традиційної педагогічної теорії зосереджувалися переважно на дидактиці, не приділяючи уваги способам і вигляду тих форм активності, які ведуть до творчого переконструювання світу» [1].

Для вивчення освітніх систем і визначення нових орієнтирів у педагогіці нині використовується системний синергетичний підхід. На думку В. Кремня для сучасного освітньо-педагогічного знання важливо виходити з того, що концепція «синергії» (або «синергізму») означає сукупну, кооперативну дію великої кількості об'єктів, у результаті якої із хаотичних, невпорядкованих станів виникають високо впорядковані просторові, часові та просторовочасові структури [1].

Отже, базуючись на основних ідеях і категоріях традиційної педагогічної теорії, синергетична освіта намагається розширити коло явищ та проблем, які охоплює теоретичний аналіз, розробити універсальні підходи для розгляду «поведінки» освітніх систем, які є за своєю суттю динамічними, нерівноважними та нестійкими [1].

Л. Євстигнєєва та Р. Євстигнєєв трактують синергетичну освіту як пізнавальний підхід, що аналізує процеси самоорганізаційної упорядкованості, з взаємодією таких протилежних тенденцій, як «стійкість» і «нестійкість», «порядок» і «хаос», «лінійність» та «нелінійність», «дезорганізація» та «організація», «необхідність» і «випадковість». [15].

Сутністю синергетичної концепції освіти $є$ іiі трансдисциплінарність у контексті виявлення взаємозв'язків як між різними галузями знань [1], що дозволяє формувати НДК не фрагментарно, а системно $з$ характерною їй самоорганізацією, динамічністю, відкритістю, нелінійністю, варіативністю.

Синергетичне знання не лише формує, але й створює можливості для аналізу, вивчення становлення нових структур у процесі кооперативної взаємодії елементів системи та досліджує процеси самоорганізації в «нелінійному» нерівноважному освітньому середовищі [1].

Принципи та методи синергетики являють собою особливу методологію, суть якої полягає в дотриманні наукових традицій, з одного боку, і відкритості до інновацій - 3 іншого. Така відкрита адаптивна методологія становлення допомагає зрозуміти основні принципи побудови моделей реальності [1].

Відомо, що сучасний науковець не стільки орієнтований на створення універсальних світоглядних засад, скільки на вирішення вузьких наукових завдань [1]. Тому наука перестає бути пов'язаною 3 освітою, оскільки основою НДД є можливість впровадження вирішених наукових завдань у професійній діяльності. Інформація виходить за межі науко- вої сфери лише в узагальненому вигляді, а інформаційний простір самої науки стає замкнутим і навчальна аудиторія припиняє бути адресатом наукового винаходу.

Нажаль, сучасна екологічна освіта обирає 3 цілісної картини світу окремі фрагменти та надає їх при викладанні таких навчальних дисциплін, як «Математика», «Фізика», «Біологія», «Загальна екологія» та ін., що призводить до того, що МФЕ обладають розрізненим інформаційним матеріалом.

Саме в системному синергетичному підході закладені можливості діалогу, креативності, індивідуального шляху розвитку особистості, як набуття нової системної якості індивіда.

Отже, основоположним підходом наукового пізнання при формуванні НДК у МФЕ визначаємо системний синергетичний підхід, тобто розглядаємо об'єкт нашого дослідження як систему, виявивши іiі компоненти, зв'язки й функції.

Системний синергетичний підхід при формуванні НДК у МФЕ потребує інших способів передачі й розповсюдження знань. На нашу думку необхідно розробляти засоби візуалізації системних синергетичних знань.

Нам близькі погляди В. Кремня, що інформаційне середовище й IT-засоби розв'язали проблему домінування викладача, тому що отримання будь-якої інформації за допомогою мережі Інтернет, швидке продукування знань, позбавляє викладача його цінності, як джерела інформації. Студент самостійно шукає інформацію, осмислює, присвоює ії як власне знання, наділяючи його власними смислами й цінністю [1].

Ми поділяємо погляди С. Курдюмова i О. Князєвої, які зазначають, що «головне - не передача знань, а володіння способами їх поповнення i швидкої орієнтації у розгалуженій системі знання, методами самоосвіти» [16].

Вважаємо, що науково-дослідницька діяльність (НДД) у процесі формування НДК є тотожною процесу самореалізації, прагненням до самовдосконалення, потреби постійно оновлювати свої знання. 3 огляду на це навчальні дисципліни та їх зміст не можуть оставатися незмінними, а повинні постійно оновлюватися у відповідь на розвиток науки. Тому одним із завдань при навчанні МФЕ $є$ не передача знань, а опанування засобами їх поповнення, орієнтація у інформаційному просторі.

Основою системної синергетичної методології формування НДК є нелінійний діалог між викладачем і студентами, інтерактивність навчання, пробуджуючі технології, а системна синергетична модель навчання є адаптивною модифікацією інтелектуального резонансу, що створюється у мозку студента. Готовність до сприйняття нових знань, уможливлює нелінійне мислення, креативність, яка є своєрідною технологією генерації нового.

Системний синергетичний підхід має забезпечити вищий ступінь розвитку креативного мислення МФЕ, при якому можливе створення альтернативних шляхів розвитку професійної діяльності, приймання нестандартних, рішень та розв'язання невизначених ситуацій. 
Спираючись на погляди В. Кремня [1], розуміємо НДД як діяльність зі створення чогось якісно нового, яка характеризується продукуванням нових результатів, здатністю по-новому вирішувати професійні завдання. Вона орієнтована не на здійснення діiі, а на реалізацію потенційних можливостей, тому креативне нелінійне мислення є умовою НДД особистості. Необхідно створити умови, щоб МФЕ усвідомив власні креативні ресурси та можливості їхньої реалізації, тобто як це знання можна використовувати при вирішенні професійних задач.

При формуванні НДК важна роль самоосвіти МФЕ, методологічною базою якої $€$ синергетика. Внутрішній сенс системного синергетичного підходу при формуванні НДК полягає у самоорганізації, стимулюванні, пробудженні суб'єкту навчання до відкритості або співпраці. У свою чергу, самоорганізація охоплює поняття дії, енергії, розподілу, зворотних зв'язків, ентропії, асиметрії, зміни стану, спільної дії, порядку.

Прикладом застосування системного синергетичного підходу при формуванні НДК у МФЕ може слугувати використання інформаційно-пошукових систем у навчальному процесі. У межах такого підходу визначальним є принцип системності, а саме інтеграція суб'єкта навчання в структуру дослідницьких і міжособистісних зв'язків.

3 точки зору нашого дослідження найбільший інтерес складають дидактичні можливості інформаційно-пошукових систем очисного обладнання (IП$\mathrm{COO})$.

Нами створено ІПСОО, призначену для вибору технічних рішень очисного обладнання для очистки газових викидів, стічних вод та твердих відходів на прикладі функціонального класу магнітних сепараторів, принципи побудови та роботи якої наведено у статті [17].

Упровадження у навчальний процес IПСОО створює умови для систематизації інформаційноресурсного забезпечення, опанування змісту науково-дослідницької діяльності в процесі навчання, розширення спектра навчальних засобів і педагогічних технологій [18]. Використання навчальної ІПСОО при формуванні НДК у МФЕ розглянуто в роботі [19].

Системний синергетичний підхід до формування НДК у МФЕ, дозволяє сформувати системне уявлення про очисне обладнання, робить можливими i дійсними кооперацію та єдність різногалузевих уявлень у суб'єкта навчання. Так, при вивченні дисципліни «Інформатика та програмування» на першому курсі МФЕ: вчяться опрацьовувати інформацію, структурувати дані; вивчають характеристики баз даних, системи управління ними, їх проектування i створення; на прикладі розробленої ІПСОО знайомляться з інформаційним та програмним забезпеченням, текстовими та табличними процесорами, системою управління базами даних екологічного спрямування.

На другому курсі, при вивчені дисципліни «Основи екологічних досліджень в галузі екологічної безпеки», на прикладі ІПСОО, МФЕ знайомляться із структурою заявки на винахід, відкриття, авторське право, патент тощо. Вивчаючи навчальні дисципліни «Урбоекологія» та «Техноекологія», на третьому курсі МФЕ здійснюють пошук очисного обладнання для очищення атмосфери, стічних вод та утилізації відходів, в залежності від умов експлуатації та вносять патентну інформацію в електронну базу даних. В магістратурі, при вивченні навчальної дисципліни «Методологія та організація наукових досліджень», МФЕ ведуть самостійний пошук патентів та здійснюють пошук прототипів при патентуванні нових технічних рішень.

ВИСНОВОК. Таким чином, системність професійної екологічної освіти зумовлює необхідність застосування системного синергетичного підходу під час формування НДК у МФЕ, що дозволяє: отримувати системну інформацію про різновиди очисного обладнання; обирати їх в залежності від умов експлуатації; запобігає інформаційній перевантаженості, помилок та непрофесіональних дій на практиці; забезпечує трансдисциплінарність розуміння глибокого та відкритого взаємозв'язку всіх елементів системи.

Результати дослідження можуть лягти в основу розробки теоретичних та методичних засад формування НДК майбутніх фахівців-екологів.

\section{ЛІТЕРАТУРА}

1. Синергетика і освіта : монографія. За ред. В. Г. Кременя. К. : Інститут обдарованої дитини, 2014. 348 c.

2. Новый энциклопедический словарь : [под ред. А. П. Горкин]. М. : Рипол Классик, 2012. 1568 с.

3. Афанасьев В. Г. Системность и общество. М. : URSS, 2016. 432 c.

4. Сагатовский В. Н. Системная деятельность и ее философское осмысление. М. : СПБ, 2003. 111 с.

5. Ильин В. В. Теория познания. Введение. Общие проблемы. М. : Изд-во МГУ, 1993. 163 с.

6. Глузман А. В. Профессионально-педагогическая подготовка студентов университета: теория и практика исследования. Киев : Просвіта, 1998. 256 с.

7. Педагогические системы, педагогические процессы и педагогические технологии в современном педагогическом знании. Г. Н. Александров, Н. И. Иванкова, Н. В. Тимошкина, Т. Л. Чшиева. Образовательные технологии и общество. 2000. № 2. C. 134-149.,

8. Прошкин В. В. Научно-теоретические основы системного похода к решению проблемы интеграции научно-исследовательской и учебной работы в университетской подготовке будущих учителей. Вестн. КазНУ. Серия „Пед. науки”. 2013. № 1. C. $29-39$.

9. Ильина Т. А. Системно-структурный подход к организации обучения. М. : Знание, 1972. 72 с.

10. Методы системного педагогического исследования. Под. ред. Н. В. Кузьминой. Л. : Изд-во Ленингр. ун-та, 1980. 172 с.

11. Сорокина Г. О. Технологія розробки и організації геотурів для школярів на території Луганщини. Вісн. Одес. держ. акад. будівництва та архітектури. № 36. За матеріалами міжнар. форуму „Меж- 
региональные проблемы экологической безопасности". Одесса ОДАБА, 2009. С. 371-376.

12. Білецька Г. А. Природничо-наукова підготовка майбутніх екологів у вищих навчальних закладах : монографія. Хмельницький : ХНУ, 2014. $378 \mathrm{c}$.

13. Введение в философию: Учеб. пособие для вузов. Авт. колл.: Фролов И. Т. и др. - 3-е изд., перераб. и доп. М.: Республика, 2003. 623 с.

14. Сериков Г. Н. Системное отображение квалификации работников образования [Электронный ресурс]. Вестник Челябинского университета. Серия 5 «Педагогика и психология». 1996. № 1(1). C. 31-41 с. Режим доступа http://www.lib.csu.ru/vch/5/1996_01/003.pdf.

15. Евстигнеева Л. П., Евстигнеев Р. Н. Экономика как синергетическая система. М.: ЛЕНАНД, 2010. 272 c.

16. Князева Е., Курдюмов С. Основания синергетики. Синергетическое мировидение. М., 2010. $256 \mathrm{c.}$
17. Soloshych I. Development of systematlics ranked structure of environmental protecting equipment for cleaning of gas emissions, wastewater and solid waste. Eastern-European Journal of Enterprise Technologies. 2016. No. 6/10 (84), pp. 17-23.

18. Creating a Learning Information Retrieval System for Selection of Electromechanical Devices for Cleaning of Gas Emissions, Wastewater and Solid. Shvedchykova I., Soloshych I., Tytiuk V. International Conference on modern electrical and energy systems November 15-17, 2017. Kremenchuk, pp. 336-340.

19. Солошич I. Використання навчальної інформаційно-пошукової системи для очистки газових викидів, стічних вод та твердих відходів при формуванні науково-дослідницької компетентності фахівців-екологів. Педагогіка формування творчої особистості у вищій і загальноосвітній школах : зб. наук. пр. Запоріжжя : КПУ, 2017. Вип. 55 (108). 624 с., C. $310-316$.

\section{SYSTEM SYNERGETIC APPROACH TO THE FORMATION OF SCIENTIFIC AND RESEARCH COMPETENCE OF FUTURE ECOLOGISTS}

\section{Soloshych}

Kremenchuk Mykhailo Ostrohradskyi National University

\section{vul. Pershotravneva, 20, 39600, Kremenchuk, Ukraine. E-mail: soloishych@gmail.com}

Purpose. The article considers the main aspects of the use of systemic synergistic approach to the formation of scientific research competence of future environmentalists. Methodology. The research was conducted using a systemic synergistic approach, using general scientific methods of analysis, synthesis and comparison. In the course of the research, the essence of the "system", "systemic synergetic approach" concepts, elements of the structure of the pedagogical system is revealed. The modern field of environmental education is considered as a complex, open, non-linear, nonequilibrium system capable of self-organization. Originality. The scientific novelty lies in the fact that in the article the structure of the pedagogical system of formation of scientific research competence of future environmentalists is defined, which consists of: the target component (purpose, task, result); the subject-object component (the interaction of teachers and students in the formation of scientific research competence); content component (forms of SRC formation in the FE); technological component (pedagogical technology of forming the SRC); motivational-stimulating component (mechanisms of stimulation of teachers and students for research activities); diagnostic component. The basis of the systematic synergetic methodology for the formation of scientific research competence is the nonlinear dialogue between the teacher and the students, the interactivity of learning, awakening technologies, and the system synergistic model of learning is an adaptive modification of the intellectual resonance that is created in the student's brain. Practical value. An example of the application of a system synergistic approach in the formation of the research competence of future environmental specialists is provided with the help of the developed information-retrieval system of the purification equipment, which allows forming integrative knowledge from ecology and other branches of knowledge (physics, chemistry, biology, and technologies). Conclusions. The system of professional environmental education necessitates the use of a systematic synergistic approach in the formation of future scientific experts in environmental sciences, which allows: to receive systemic information about varieties of purification equipment; choose them depending on the operating conditions; prevents information overload, errors and non-professional actions in practice; provides transdisciplinary understanding of the deep and open interconnection of all elements of the system. The results of the research may form the basis for further scientific analysis that is the development of theoretical and methodological foundations for the formation of scientific research competence of future specialists-ecologists.

Key words: systemic synergetic approach, information retrieval system of purification equipment, scientific research competence, future specialists-ecologists.

\section{REFERENCES}

1. Kremen, V. H. (2014), "Synerhetyka i osvita: monohrafiia" [Synergetics and education: monograph], Kyiv: Instytut obdarovanoi dytyny.

2. Prokhorov, A. M. (1991), Bolshoy entsiklopedicheskiy slovar [Big Encyclopedic Dictionary], Moskva: Radianska intsyklopediia.
3. Afanasev, V. H. (1981), "Obshchestvo: systemnost, poznanye y upravlenye" [Society: systematic, knowledge and management], Moskva: Polytyzdat.

4. Sahatovskyi, V. N. (1980), "Sistemnaya deyatelnost $i$ ee filosofskoe osmyislenie" [Systemic activity and its philosophical understanding], Moskva: Nauka. 
5. Ilin, V. V. (1993), “Teoriya poznaniya. Vvedenie. Obschie problemyi" [Theory of knowledge. Introduction Common problems], Moskva: Izdatelstvo MGU.

6. Gluzman, A. V. (1998), "Professionalnopedagogicheskaya podgotovka studentov universiteta: teoriya i praktika issledovaniya" [Professional and pedagogical training of university students: theory and practice of research], Kyev: Prosvita.

7. Aleksandrov, G. N., Ivankova, N. I., Timoshkina, N. V., Chshieva, T. L. (2000), "Pedagogicheskie sistemyi, pedagogicheskie protsessyi i pedagogicheskie tehnologii $\mathrm{v}$ sovremennom pedagogicheskom znanii [Pedagogical systems, pedagogical processes and pedagogical technologies in modern pedagogical knowledge]", Obrazovatelnyie tehnologii i obschestvo, № 2, p. $134-149$.

8. Proshkin, V. V. (2014), Teoretyko-metodychni osnovy intehratsii naukovo-doslidnoi ta navchalnoi roboty $v$ universytetskii pidhotovtsi maibutnikh uchyteliv, Doctor's thesis. State institution Luhansk National University, Luhansk, Ukraine.

9. Ilina, T. A. (1972), Sistemno-strukturnyiy podhod $k$ organizatsii obucheniya [System-structural approach to the organization of training], Moskva: Znanie.

10. Kuzmina, N. V. (1980), “Metodyi sistemnogo pedagogicheskogo issledovaniya " [Methods of systemic pedagogical research], Leningrad: Izdatelstvo Leningradskogo universiteta.

11. SorokIna, G. O. (2011), Teorlya I praktika formuvannya profesIynoYi gotovnostI maybutnIh fahIvtsIv u galuzI turizmu do ekologIchnogo vihovannya uchnIv, Doctor's thesis. State institution Luhansk National University, Luhansk, Ukraine.

12. Biletska, H. A. (2015), "Teoretychni $i$ metodychni zasady pryrodnycho-naukovoi pidhotovky maibutnikh ekolohiv $u$ vyshchykh navchalnykh zakladakh", State institution Luhansk National University, Luhansk, Ukraine.

13. Frolov, I. T. (2003), "Vvedenie v filosofiyu: Ucheb. posobie dlya vuzov" [Introduction to philoso- phy: Textbook. manual for universities], Moskva: Respublika.

14. Serikov, G. N. (1996), "Sistemnoe otobrazhenie kvalifikatsii rabotnikov obrazovaniya [System mapping of education staff]", Vestnyk Cheliabynskoho unyversyteta. "Pedahohyka y psykholohyia», Vol. 1(1), pp. 31-41, http://www.lib.csu.ru/vch/5/1996_01/003.pdf.

15. Evstigneeva, L. P., Evstigneev, R. N. (2010). "Ekonomika kak sinergeticheskaya Sistema" [Economics as a synergistic system], Moskva: LENAND.

16. Knyazeva, E., Kurdyumov, S. (2018), "Osnovaniya sinergetiki. Sinergeticheskoe mirovidenie" [The foundations of synergy. Synergistic world view], Moskva: Knizhnyiy dom "LIBROKOM".

17. Soloshych, I., Shvedchykova, I. (2016), "Rozrobka ranhovoi struktury systematyky pryrodookhoronnoho obladnannia dlia ochystky hazovykh vykydiv, stichnykh vodi tverdykh vidkhodiv [Development of systematlics ranked structure of environmental protecting equipment for cleaning of gas emissions, wastewater and solid waste]", VostochnoEvropeyskiy zhurnal peredovyih tehnologiy, Vol. 6/10 (84), pp. 17-23.

18. Shvedchykova, I., Soloshych, I., Tytiuk, V. (2017), "Sozdanie sistemyi poiska uchebnoy informatsii dlya vyibora elektromehanicheskih ustroystv dlya ochistki gazovyih vyibrosov, stochnyih vod i tverdyih veschestv" [Creating a Learning Information Retrieval System for Selection of Electromechanical Devices for Cleaning of Gas Emissions, Wastewater and Solid], Mezhdunarodnaya konferentsiya po sovremennyim elektricheskim i energeticheskim sistemam, pp. 336-340.

19. Soloshych, I. (2017), "Use of educational information retrieval system for the purification of gas emissions, sewage and solid wastes in the formation of scientific research competence of environmental specialists", Pedahohika formuvannia tvorchoi osobystosti $u$ vyshchii $i$ zahalnoosvitnii shkolakh: zb. nauk. pr., Vol. 55 (108), pp. 310-316. 